\title{
Denitrification in a soft bottom lake: evaluation of laboratory incubations
}

\author{
Nils Risgaard-Petersen*, Susanne Skårup, Lars Peter Nielsen \\ Institute of Biological Sciences, Department of Microbial Ecology, University of Aarhus, DK-8000 Århus C, Denmark
}

\begin{abstract}
Annual benthic denitrification in a shallow soft bottom lake was estimated in laboratoryincubated sediment cores, using the isotope pairing technique. Rates were $<30 \%$ of the estimate calculated from nitrogen mass balance of the lake. To investigate this discrepancy, in situ measurements were performed in flexible enclosures to which ${ }^{15} \mathrm{NO}_{3}{ }^{-}$was added. Accumulation of ${ }^{29} \mathrm{~N}_{2}$ and ${ }^{30} \mathrm{~N}_{2}$ in the sediment and water column was measured and the loss to the atmosphere was estimated from depletion of argon, added in excess to the water of the enclosures. The calculated denitrification activities in the enclosures were 6 to 26 times higher than the activity in the incubated cores. We suggest that denitrification in situ was enhanced by wave forces, increasing the transport of oxygen and nitrate into these soft sediments. Such transport is not simulated by conventional stirring of the water column in laboratory incubations, which consequently may underestimate the in situ activity.
\end{abstract}

KEY WORDS: Rigid core tubes - Flexible enclosures - In situ measurements - Nitrogen mass balance

\section{INTRODUCTION}

Denitrification activity is typically measured from either large-scale nitrogen mass balances or from rates of nitrogen removal or nitrogen gas production in sampled sediments.

The nitrogen mass balance approach is commonly used in lakes and other systems, where input and output of combined nitrogen can be estimated (e.g. Messer \& Brezonik 1978, Jensen et al. 1992, Windolf et al. 1996). Denitrification is calculated as the input from streams, groundwater, precipitation and nitrogen fixation minus the loss through outlets and sediment burial.

Measurements of denitrification in sampled sediments include techniques like $\mathrm{NO}_{3}{ }^{-}$depletion (Andersen 1977), acetylene block (Sørensen 1978), $N_{2}$ flux (Seitzinger et al. 1980), ${ }^{15} \mathrm{~N}$-tracer techniques (Nishio et al. 1983, Nielsen 1992) or changes in $\mathrm{N}_{2} /$ Ar ratios (Kana et al. 1994). The techniques are based on incubations of representative sediment samples, isolated in core tubes or benthic chambers (e.g. Devol 1991, Rysgaard et al. 1995, Kana et al. 1998, Trimmer et al.

•E-mail: nils.risgaard-petersen@biology.aau.dk
1998). Mixing of the water column inside these containers is typically provided by stirring devices like rods or discs. Such mixing is assumed to approach in situ hydrodynamic conditions.

Only a few studies compare denitrification rates obtained in sampled sediment with rates obtained from large-scale nitrogen mass balances. Good correspondence was found in a small estuary (Nielsen et al. 1995) and in 2 deep lakes (Mengis et al. 1997). In both of these studies, the isotope pairing technique (Nielsen 1992) was used to estimate the activity in laboratoryincubated sediment, and the nitrogen mass balance approach was applied to the entire study area. Andersen (1977), on the other hand, found that denitrifiration, measured from $\mathrm{NO}_{3}{ }^{-}$depletion in the water overlying laboratory-incubated lake sediment cores, was only about half of the values obtained by the mass balance approach. Van Luijn et al. (1996) found a similar difference when nitrogen gas production of sediment from a shallow lake was measured with the isotope pairing technique. In their study, rates obtained with the $N_{2}$ flux method, however, agreed well with the nitrogen mass balance estimate. The studies of Andersen (1977) and van Luijn et al. (1996) were conducted in shallow lakes with a mean depth ranging between 
1.6 and $5 \mathrm{~m}$. Although the inconsistency between laboratory measurements and the mass balance approach might be due to shortcomings of the applied denitrification assay (cf. Seitzinger et al. 1993), it is possible that laboratory measurements in general fail in such lakes, because of inadequate simulations of the in situ conditions.

In the present study we wanted to investigate this possibility. By means of the isotope pairing technique we measured annual nitrogen gas production in laboratory-incubated sediment, collected in a shallow soft bottom lake. Rates obtained with that technique were compared with rates obtained from the nitrogen mass balance of the whole lake. The 2 methods produced different results, but apparently they measured actual denitrification activity in the laboratory-incubated cores and in the lake, respectively. We assumed that the laboratory incubation technique failed to simulate factors that controlled denitrification in situ, and the incubation technique was therefore evaluated by comparing rates of nitrogen gas production obtained in the laboratory with rates obtained in the field in flexible enclosures. Hansen et al. (1991) previously found that $\mathrm{NO}_{3}^{-}$disappearance inside and outside such enclosures was similar during a 3 mo study in the same lake, which suggests that the enclosures did not change the nitrogen removal capacity of the lake sediment. In this paper we report and discuss data from both the annual measurements and from the comparison experiment.

\section{MATERIALS AND METHODS}

Study site. The study was performed in Lake Søbygaard, a small $\left(0.39 \mathrm{~km}^{2}\right)$, shallow (mean depth: $100 \mathrm{~cm}$; maximum depth: $190 \mathrm{~cm}$ ) hypertrophic lake in central Jutland, Denmark $\left(56.15^{\circ} \mathrm{N}, 9.48^{\circ} \mathrm{E}\right)$. The lake is exposed to prevailing southwestern winds, but otherwise protected by slopes and forest. Phragmittes sp. grows sparsely along the banks, while submerged vegetation is absent due to light limitation. Phytoplankton production is $275 \pm 9 \mathrm{mmol} \mathrm{C} \mathrm{m} \mathrm{C}^{-2}$ (Jeppesen et al. 1997) and Secchi depth ranges between 55 and $85 \mathrm{~cm}$ (Jeppesen et al. 1990).

Ip to $90 \%$ of the water is supplied from a nitrogenrich creek flowing into the east end of the lake. Groundwater fed springs are responsible for the remainder. The hydraulic residence time is 18 to $27 \mathrm{~d}$ (Jensen et al. 1992), and the nitrogen load for the 1985-1995 period was 11.4 $\pm 1 \mathrm{mmol} \mathrm{N} \mathrm{m}^{-2} \mathrm{~d}^{-1}$ (Jeppesen et al. 1998). The sediment of the lake is organic-rich (25 to $35 \%$ of sediment dry weight is organic matter in the upper centimeter) soft mud with a porosity of 0.92 (vol./vol.).

Nitrogen gas production in sampled sediment cores. Rates of denitrification were measured with the
${ }^{15} \mathrm{~N}$ isotope pairing technique in intact sediment cores collected 8 separate times during the May 1992 to May 1993 period. Measurements were only performed in darkness, as no light reached the sediment surface in situ. The cores ( $\mathrm{n}=4$ or 5 ) were sampled at the central part of the lake (depth: $150 \mathrm{~cm}$ ) in Plexiglas tubes (inner diameter: $3.6 \mathrm{~cm}$, height: $20 \mathrm{~cm}$ ). Filtered (glass fiber $\mathrm{GF} / \mathrm{C}$ filters) water samples for $\mathrm{NO}_{3}{ }^{-}+\mathrm{NO}_{2}{ }^{-}$analysis were collected at the field site in $20 \mathrm{ml}$ polyethylene vials and frozen $\left(-20^{\circ} \mathrm{C}\right)$ on return to the laboratory. Lake water for the incubations was collected in 50 l polyethylene jars.

In the laboratory the height of the sediment was adjusted to $\sim 5 \mathrm{~cm}$, and the tubes were hereafter placed in an open tank with lake water, held at in situ temperature. A $1 \mathrm{~cm}$ long Teflon-coated rotating ( $60 \mathrm{rpm}$ ) magnet, mounted inside the tubes, kept the water column above the sediment stirred. ${ }^{15} \mathrm{~N}$-labeled $\mathrm{NO}_{3}{ }^{-}(50$ to $100 \mu \mathrm{M})$ was then added to the water in the tank, and this ${ }^{15} \mathrm{~N}$-enriched lake water was carefully mixed with the water above the sediment cores. The resulting ${ }^{15} \mathrm{~N}$ enrichment of the $\mathrm{NO}_{3}{ }^{-}$pool in the water column ranged from 20 to $99{ }^{15} \mathrm{~N}$ atom $\%$ due to seasonal variations of the in situ $\mathrm{NO}_{3}{ }^{-}$concentration (see Fig. 5).

Approximately $10 \mathrm{~min}$ after tracer addition, the core tubes were sealed with rubber stoppers. The incubation of the individual cores was terminated at regular time intervals within $1.7 \mathrm{~h}$ (summer) or $9 \mathrm{~h}$ (winter) of incubation. Total incubation time, determined after preliminary measurements of the sediment $\mathrm{O}_{2}$ demand, was set to ensure that change in $\mathrm{O}_{2}$ never exceeded $20 \%$ of the initial $\mathrm{O}_{2}$ concentration. The incubation of the cores was terminated by adding $0.5 \mathrm{ml}$ $7 \mathrm{M} \mathrm{ZnCl}_{2}$ and subsequently mixing the sediment and the water column with a PVC rod. A sample of the resultant sediment-water suspension was collected with a syringe in order to determine the amount of ${ }^{15} \mathrm{~N}_{2}$ that accumulated in both the sediment and the water column during the incubation. This sample was transferred to $12 \mathrm{ml}$ giass vials (Exetainers, Labco, High Wycombe, UK), preserved with an additional $250 \mu$ l $7 \mathrm{M} \mathrm{ZnCl}_{2}$ and stored at room temperature for later ${ }^{29} \mathrm{~N}_{2}$ and ${ }^{30} \mathrm{~N}_{2}$ determinations.

During June, August and September 1992 denitrification was measured at 2 different ${ }^{15} \mathrm{NO}_{3}{ }^{-}$concentrations in the water overlying the sediment. These measurements were performed to verify the fundamental requirements of the isotope pairing technique, i.e. first order dependency of denitrification with respect to $\mathrm{NO}_{3}{ }^{-}$concentration in the water column and uniform mixing of ${ }^{14} \mathrm{NO}_{3}{ }^{-}$and ${ }^{15} \mathrm{NO}_{3}{ }^{-}$in the denitrification zone (Nielsen 1992).

To verify that the station selected for annual denitrification measurements was representative for the 
whole lake, denitrification was measured at 3 different sites during October 1992: the east end (depth: $65 \mathrm{~cm}$ ), the west end (depth: $100 \mathrm{~cm}$ ), and at the station described above.

Nitrogen gas production in field enclosures. During May and September 1996, denitrification activity was measured with the isotope pairing technique both in airexposed enclosures installed in the lake and in laboratory-incubated cores. Field and laboratory incubations were conducted under similar nutrient, $\mathrm{O}_{2}$ and temperature conditions. The temperature of the water column was $13^{\circ} \mathrm{C}, \mathrm{O}_{2}$ was close to saturation $(297 \mu \mathrm{M})$, and $\mathrm{NO}_{3}{ }^{-}$ concentration in the water column was below $1 \mu \mathrm{M}$.

The enclosure (inner diameter: $150 \mathrm{~cm}$; height: $120 \mathrm{~cm}$ ) was constructed from a transparent flexible PVC bag, fixed to a metal cylinder (Fig. 1). The day before incubation was initiated, the enclosure was placed in the western part of the lake at a water depth of $\sim 85 \mathrm{~cm}$. The metal cylinder was forced into the sediment and fixed to wooden poles, while the PVC bag was left below the water surface, to allow free exchange with ambient lake water. Just before the incubation began, the upper rim of the bag was extended $\sim 40 \mathrm{~cm}$ above the surface of the water and tightened to the poles. Wave amplitude and frequency in the enclosure and the lake were similar, as judged from visual observations.

Argon-saturated lake water (15 l) with ${ }^{15} \mathrm{NO}_{3}{ }^{-}$was gently mixed into the water of the enclosure without resuspending the sediment. The ${ }^{15} \mathrm{~N}$ isotope was added to a final concentration of $100 \mu \mathrm{M}$ in May and to $30 \mu \mathrm{M}$ in September. The high initial working concentration of ${ }^{15} \mathrm{NO}_{3}{ }^{-}$in May was chosen to prevent phytoplankton from exhausting the tracer. In order to determine rates of ${ }^{29} \mathrm{~N}_{2}$ and ${ }^{30} \mathrm{~N}_{2}$ production, it was necessary to determine both the amount of ${ }^{15} \mathrm{~N}_{2}$ that accumulated in the enclosed water column plus the sediment and the amount of ${ }^{15} \mathrm{~N}_{2}$ that was lost to the atmosphere during the incubation. Evolution of ${ }^{29} \mathrm{~N}_{2}$ and ${ }^{30} \mathrm{~N}_{2}$, and depletion of $\mathrm{Ar}$ in the enclosure were therefore followed for $24 \mathrm{~h}$, by collecting samples from the entire water column and subsamples of the sediment plus the water column, for later gas determinations.

Water samples from the entire water column of the enclosure were collected in duplicate with a $100 \mathrm{~cm}$ long $0.3 \mathrm{~cm}$ i.d. glass tube. The glass tube was vertically immersed in the water column so gently that the meniscus always stayed at the lake surface. Just before the tip of the tube reached the bottom of the lake, the upper end was closed with a finger, and the tube, containing a sample of the intact water column, was redrawn from the enclosure. Additional samples of the bottom water were collected with the upper tube end sealed until a few cm above the bottom. Sampling of the bottom water was performed to investigate if the

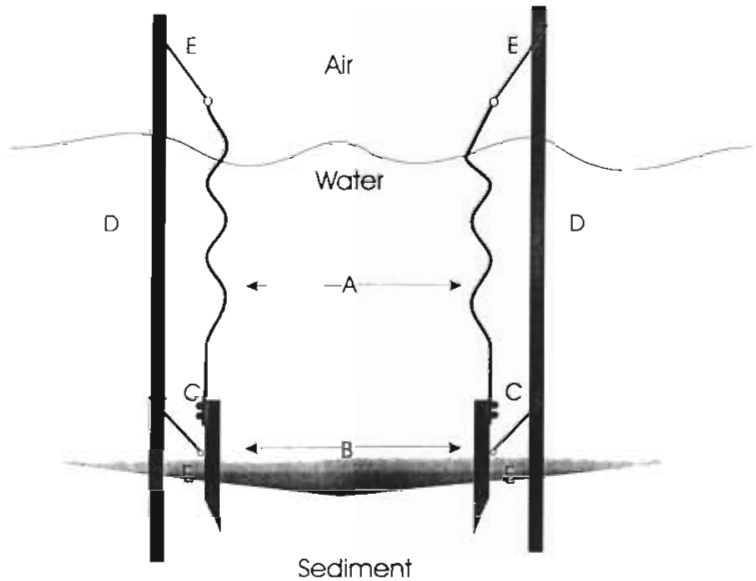

Fig. 1. Enclosure used for field incubations. A PVC bag $(A)$ is fixed to a metal cylinder (B) with nylon strips (C). The enclosure is fixed to wooden poles (D) by wires (E)

water column was stratified or mixed during the incubation. All water samples were transferred to $12 \mathrm{ml}$ glass vials (Exetainer, Labco) and preserved with $250 \mu \mathrm{l} \mathrm{M} \mathrm{ZnCL}_{2}$. The samples were stored for less than $5 \mathrm{~d}$ in the laboratory before the dissolved gases were determined.

Subsamples of sediment plus the water column were collected as intact cores in triplicate with a Plexiglas tube (inner diameter: $5.5 \mathrm{~cm}$; height: $100 \mathrm{~cm}$ ). The tube was forced $\sim 10 \mathrm{~cm}$ into the sediment, sealed with a rubber stopper, and then redrawn from the enclosure. After adding $1 \mathrm{ml} 7 \mathrm{MZnCL}_{2}$ to the cores, the water and the sediment were mixed and a sample of the slurry was transferred to $12 \mathrm{ml}$ glass vials (Exetainer, Labco) and preserved with additional $250 \mu \mathrm{l} 7 \mathrm{M} \mathrm{ZnCL}_{2}$. Like the samples from the water column, the sedimentwater samples were stored for less than $5 \mathrm{~d}$ in the laboratory before the gas concentration was determined.

Intact cores ( $n=6)$, for the laboratory measurements, were collected in Plexiglas tubes (inner diameter: $5.2 \mathrm{~cm}$; height: $30 \mathrm{~cm}$ ) close to the enclosure. The cores were allowed to equilibrate in the laboratory for $12 \mathrm{~h}$ in a darkened tank with air-saturated lake water, before incubation was initiated. The water column above the sediment was stirred with a $2.5 \mathrm{~cm}$ Teflon-coated magnet $(60 \mathrm{rpm})$, positioned about $5 \mathrm{~cm}$ above the sediment surface. Denitrification measurements were performed as described in the previous section.

Nitrogen mass balance of the lake. Denitrification rates, calculated from the nitrogen mass balance of the lake from May 1992 to May 1993, were provided by J. P. Jensen (National Environmental Research Institution, Silkeborg, Denmark, pers. comm.). The nitrogen mass balance was based on frequent $(6 \mathrm{~h})$ measurements of nitrogen concentrations (DIN and DON) in the inlet and outlet of the lake, daily nitrogen measure- 

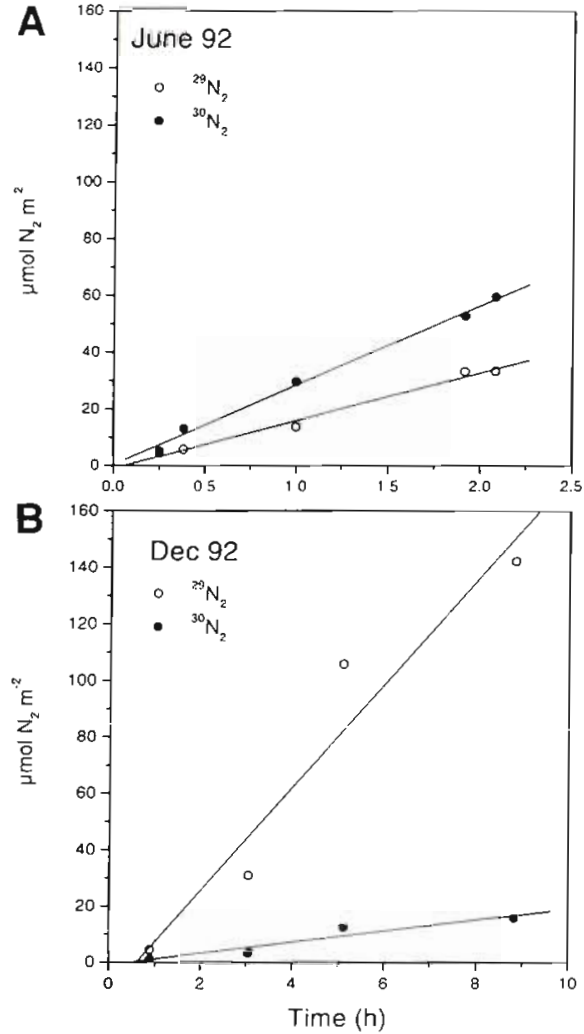

Fig. 2. Linear accumulation of ${ }^{29} \mathrm{~N}_{2}$ and ${ }^{30} \mathrm{~N}_{2}$ in the sediment and the water column of laboratory-incubated samples during a summer (A: June 1992, $\mathrm{r}^{2}=0.99$ ) and a winter (B: December $1992, r^{2}>0.90$ ) incubation. Each paired ${ }^{29} \mathrm{~N}_{2} /{ }^{30} \mathrm{~N}_{2}$ point represents data from a single core. Note different scales on the time axes in June and December

ments in the mid lake, and approximately monthly measurements in the springs. The transport of nitrogen was calculated by multiplying values of nitrogen concentration with measured values for daily water discharge. Quarterly denitrification was estimated from differences between nitrogen load, washout, storage and burial. Storage was calculated from differences in nitrogen content of the lake water during yearly or quarterly periods, and burial was calculated from iron mass balances and the iron to nitrogen ratio in the sediment. For further details about the mass balance of the lake see Jensen et al (1992)

Analyses. Gas samples of $250 \mu \mathrm{l}$ for $\mathrm{Ar}_{1}{ }^{29} \mathrm{~N}_{2}$ and ${ }^{30} \mathrm{~N}_{2}$ determinations were extracted from the water samples in the glass vials as described by Risgaard-Petersen \& Rysgaard (1995), and subsequently analyzed on a GCMS system (Sira Series II, VG Isotech, Middlewich, UK), described by Nielsen (1992). Gas samples extracted from air-saturated deionized water samples were used as reference.

Lake water $\mathrm{NO}_{3}{ }^{-}+\mathrm{NO}_{2}{ }^{-}$concentrations were determined on a Flow Injection Analyzer (Tecator, Hö- ganäss, Sweden), using the sulphanilamide-napthylene-diamide method after reduction of $\mathrm{NO}_{3}{ }^{-}$to $\mathrm{NO}_{2}{ }^{-}$ by a cadmium column (Grasshoff et al. 1983).

Calculations. Rates of denitrification of in situ $\mathrm{NO}_{3}$ $\left({ }^{14} \mathrm{NO}_{3}{ }^{-}\right)$were determined using the principle of isotope pairing (Nielsen 1992). It was assumed that the added ${ }^{15} \mathrm{NO}_{3}{ }^{-}$mixed homogeneously with the ${ }^{14} \mathrm{NO}_{3}{ }^{-}$ pool in the sediment and that the $2 \mathrm{NO}_{3}{ }^{-}$species were reduced at a rate proportional to their respective mole fractions. Denitrification of in situ $\mathrm{NO}_{3}^{-}$could then be calculated from the production rates of ${ }^{29} \mathrm{~N}_{2}$ and ${ }^{30} \mathrm{~N}_{2}$ using the equation of Nielsen (1992):

Denitrification of in situ $\mathrm{NO}_{3}{ }^{-}=$

$$
\frac{F^{29}}{2 \times F^{30}} \times\left(F^{29}+2 \times F^{30}\right)
$$

where $F^{29}$ and $F^{30}$ are the production rates of ${ }^{29} \mathrm{~N}_{2}$ and ${ }^{30} \mathrm{~N}_{2}$.

Rates of ${ }^{29} \mathrm{~N}_{2}$ and ${ }^{30} \mathrm{~N}_{2}$ production in the core tubes were calculated from the slope of the regression line, obtained from plots of ${ }^{29} \mathrm{~N}_{2}$ or ${ }^{30} \mathrm{~N}_{2}\left(\mu \mathrm{mol} \mathrm{m}{ }^{-2}\right)$ versus time (h); see Fig. 2.

Production rates of ${ }^{29} \mathrm{~N}_{2}$ and ${ }^{30} \mathrm{~N}_{2}$ in the enclosure, installed in the lake, were calculated from ${ }^{15} \mathrm{~N}_{2}$ accumulation in the sediment and the water column plus the amount lost to the atmosphere (Fig. 3). The water column in the enclosure was well mixed in May and September 1996, as indicated by identical concentrations of ${ }^{15} \mathrm{~N}_{2}$ or Ar in the bottom and surface water $(t-$ test, hypothesized mean difference $=0, p \gg 0.05$, data not shown). The loss of ${ }^{15} \mathrm{~N}_{2}$ to the atmosphere was therefore proportional to the difference between the actual concentration in the water column $\left[{ }^{15} \mathrm{~N}_{\mathrm{w}}(t)\right]$ and the concentration at air saturation $\left({ }^{15} \mathrm{~N}_{0}\right)$, as shown by Broecker \& Peng (1974):

$$
\text { Loss }=a\left[{ }^{15} \mathrm{~N}_{o}-{ }^{15} \mathrm{~N}_{w}(t)\right]
$$

where $a$ is the air-water transfer coefficient for $N_{2}$. The air-water transfer coefficient for $\mathrm{N}_{2}$ was calculated as the transfer coefficient for Ar multiplied with the ratio between the diffusion coefficients for $\mathrm{N}_{2}$ and $\mathrm{Ar}$

Table 1. Denitrification activity measured with different concentrations of ${ }^{15} \mathrm{NO}_{3}$ in the water overlying the sediment. The standard error of the mean is presented in parentheses $(n=4)$

\begin{tabular}{|cccc}
$\begin{array}{l}\text { Date } \\
(1992)\end{array}$ & $\begin{array}{c}\text { Concentration } \\
\text { of added }{ }^{15} \mathrm{NO}_{3}- \\
(\mu \mathrm{M})\end{array}$ & $\begin{array}{c}\text { Denitrification } \\
\text { of in situ }{ }^{14} \mathrm{NO}_{3} \\
\left(\mu \mathrm{mol} \mathrm{m} \mathrm{m}^{-2} \mathrm{~h}^{-1}\right)\end{array}$ & $\begin{array}{c}\text { Denitrification } \\
\text { of added }{ }^{15} \mathrm{NO}_{3}^{-} \\
\left(\mu \mathrm{mol} \mathrm{m} \mathrm{m}^{-2} \mathrm{~h}^{-1}\right)\end{array}$ \\
\hline 16 Jun & 49 & $19.7(1.7)$ & $70(4)$ \\
& 85 & $23(2)$ & $120(20)$ \\
11 Aug & 47 & $15.6(1.2)$ & $26(3)$ \\
& 106 & $12.1(1.1)$ & $39(2)$ \\
$17 \mathrm{Sep}$ & 41 & $66(8)$ & $13.2(1.4)$ \\
& 88 & $71.9(1.7)$ & $37(3)$
\end{tabular}



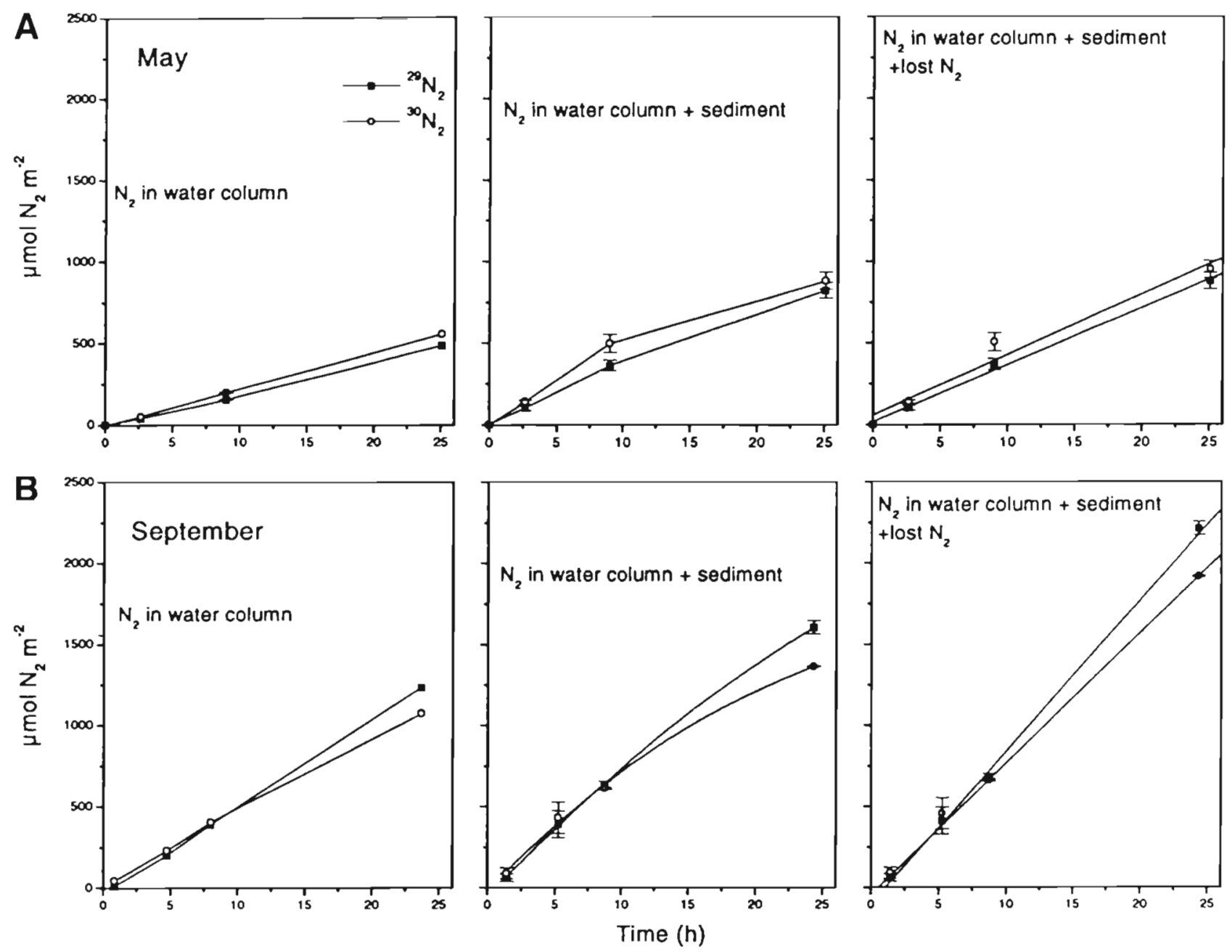

Fig. 3. Accumulation of ${ }^{15} \mathrm{~N}_{2}$ in the water column of the field enclosure, in the sediment plus the water column, and in the sediment, the water column plus the amount of ${ }^{15} \mathrm{~N}_{2}$ lost to the atmosphere in (A) May and (B) September. Error bars represent standard error of the mean $(n=3)$

(Broecker \& Peng 1974). The transfer coefficient for Ar was calculated from Ar depletion from the enclosure, assuming a first order decrease in concentration with time (Fig. 4).

\section{RESULTS}

The isotope pairing technique adapted to core-tube incubations

The evolution of ${ }^{29} \mathrm{~N}_{2}$ and ${ }^{30} \mathrm{~N}_{2}$ in the ${ }^{15} \mathrm{NO}_{3}{ }^{-}$ amended core tubes could be described as a linear function of time $\left(0.87<\mathrm{r}^{2}<0.99\right.$ for all incubations; see Fig. 2 for examples), suggesting constant gas production during the incubation period. The rate of denitrification of ${ }^{15} \mathrm{NO}_{3}{ }^{-}$increased when ${ }^{15} \mathrm{NO}_{3}{ }^{-}$was elevated, but denitrification of in situ $\mathrm{NO}_{3}^{-}\left({ }^{14} \mathrm{NO}_{3}^{-}\right)$was inde- pendent of the ${ }^{15} \mathrm{NO}_{3}{ }^{-}$concentration in the water column (Table 1). This suggests first order dependency of denitrification with respect to $\mathrm{NO}_{3}{ }^{-}$, and homogenous mixing of ${ }^{14} \mathrm{NO}_{3}{ }^{-}$and ${ }^{15} \mathrm{NO}_{3}{ }^{-}$in the denitrification zone (cf. Nielsen 1992).

Denitrification rates at the 3 different sites in the lake were similar (east end: $2.7 \pm 0.33$ [mean $\pm \mathrm{SE}$ ], center: $2.1 \pm 0.28$, west end: $2.3 \pm 0.24 \mathrm{mmol} \mathrm{N} \mathrm{m} \mathrm{N}^{-2} \mathrm{~d}^{-1}$, hypothesized mean difference $=0, p \gg 0.05$ ). This indicates a homogeneous sediment environment and justifies that only a single site was selected for the annual denitrification measurements.

Denitrification activity, measured as nitrogen gas production in the laboratory during 1992 to 1993, showed a marked seasonal variation (Fig. 5). Maximum rates $\left(\sim 2.4 \mathrm{mmol} \mathrm{N} \mathrm{m}^{-2} \mathrm{~d}^{-1}\right)$ were observed during winter and late fall when $\mathrm{NO}_{3}{ }^{-}$in the water column peaked. Lowest activity $\left(<0.3 \mathrm{mmol} \mathrm{N} \mathrm{m}^{-2} \mathrm{~d}^{-1}\right)$ was 


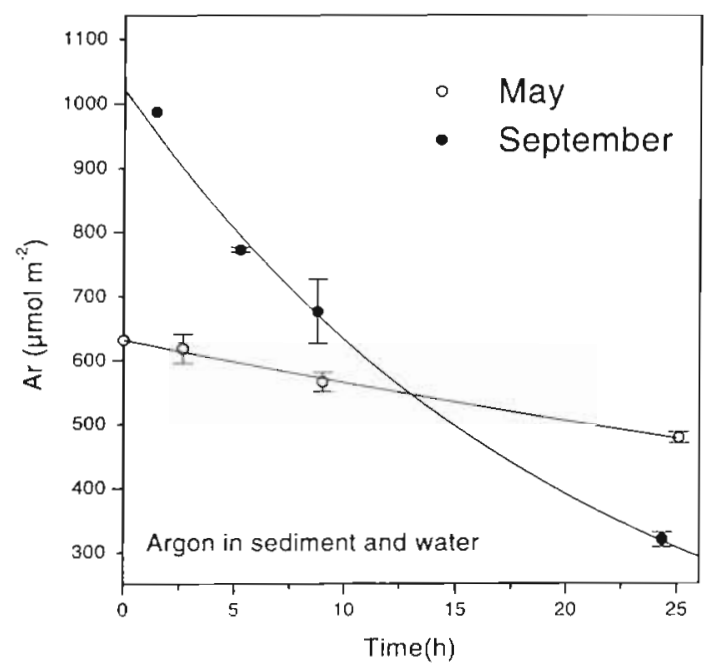

Fig. 4. Decrease of excess argon in the sediment and the water column of the enclosure. Error bars represent standard error of the mean ( $\mathrm{n}=3$ ). In May the transfer coefficient was $-0.011 \pm 0.002 \mathrm{~h}^{-1}$, assuming exponential decay. In September the transfer coefficient was $-0.048 \pm 0.003 \mathrm{~h}^{-1}$

observed during summer months when $\mathrm{NO}_{3}^{-}$was $<1 \mu \mathrm{M}$. Annual denitrification was approximately $30 \%$ of the activity estimated by the nitrogen mass balance approach $\left(511 \pm 18\right.$ vs $\left.1880 \mathrm{mmol} \mathrm{N} \mathrm{m}^{-2} \mathrm{yr}^{-1}\right)$. According to the laboratory measurements of nitrogen gas production, less than $13 \%$ of the nitrogen load to the lake (4067 mmol $\mathrm{N} \mathrm{m}^{-2} \mathrm{yr}^{-1}$ for the 1992 to 1993 period, J. P. Jensen pers. comm.) was lost by denitrification. The nitrogen mass balance approach, however, proposed that denitrification removed approximately $46 \%$ of the nitrogen input.

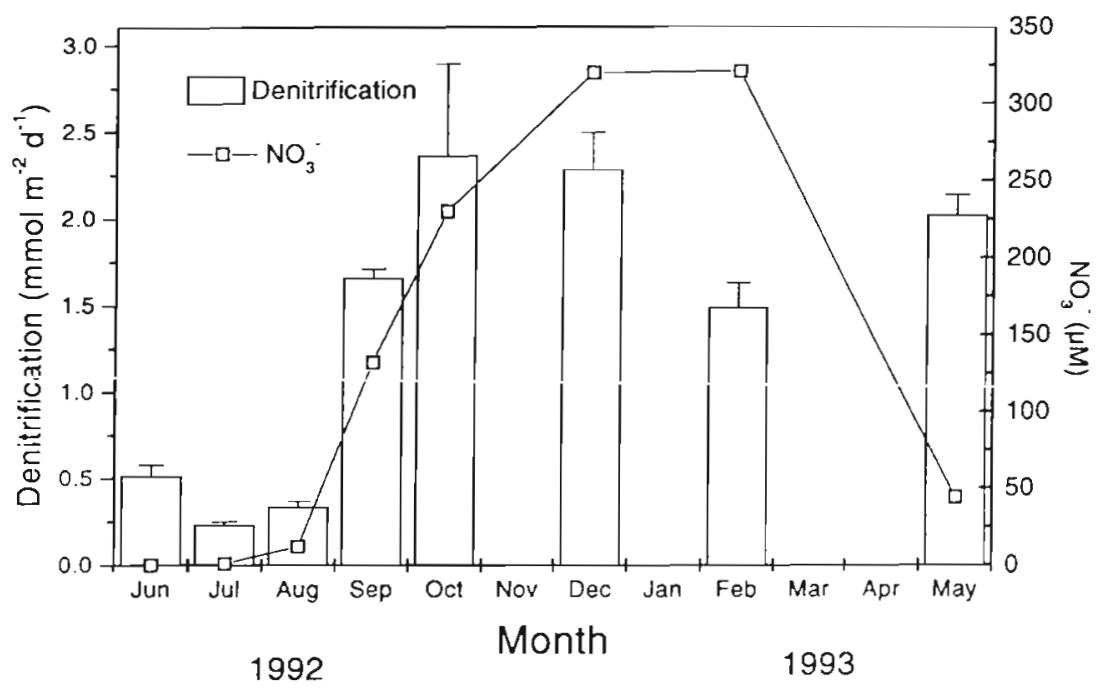

Fig. 5. Annual denitrification activity estimated in laboratory-incubated sediment and lake water $\mathrm{NO}_{3}{ }^{-}$concentration. Columns represent the mean denitrification activity $(n=4)$; error bars represent standard error of the mean

\section{The isotope pairing technique adapted to field incubations}

Linear ${ }^{29} \mathrm{~N}_{2}$ and ${ }^{30} \mathrm{~N}_{2}$ evolution with time was observed during both the May and the September incubations $\left(I^{2}>0.97\right)$, when the amount of ${ }^{15} \mathrm{~N}_{2}$ lost to the atmosphere was included in the pool of produced gas (Fig. 3). This shows that rates of ${ }^{29} \mathrm{~N}_{2}$ and ${ }^{30} \mathrm{~N}_{2}$ production were constant during the $24 \mathrm{~h}$ of incubation. Less than $7 \%$ of the ${ }^{15} \mathrm{~N}_{2}$ gas produced in the enclosure during the May 1996 experiment was lost during the incubation, but in September approximately $30 \%$ of the produced ${ }^{15} \mathrm{~N}_{2}$ gas was lost from the enclosure (Fig. 3). This difference was probably caused by different wind velocities, regulating the air-water exchange of gases. The average wind velocities, measured at the nearest meteorological station, Ødum II, Denmark $\left(56.18^{\circ} \mathrm{N}\right.$, $10.8^{\circ} \mathrm{E}$ ), were $2.8 \pm 0.3 \mathrm{~m} \mathrm{~s}^{-1}$ during the May measurements and $5.2 \pm 0.7 \mathrm{~m} \mathrm{~s}^{-1}$ during the September measurements. Although Ødum is situated approximately $20 \mathrm{~km}$ northeast from Lake Søbygaard and local wind conditions may differ, the 4-fold higher air-water gas exchange rates in September compared to May (Fig. 4) are consistent with a 2 -fold higher wind velocity, since the rate of exchange is roughly proportional to the square of the wind velocity (Kanwisher 1963).

In May 1996 denitrification rates measured in the enclosure installed in the field exceeded laboratorygenerated rates by a factor of $\sim 6$, whereas in September 1996, when the wind velocity was highest, the activity in the enclosure was $\sim 26$ times higher than the activity measured in the laboratory-incubated sediment cores (Fig. 6). Nitrate concentrations in the field enclosures and in the laboratory-incubated cores were $<1 \mu \mathrm{M}$ both in May and in September. The rates obtained in the laboratory in 1996 were similar to the rates in 1992 to 1993, when $\mathrm{NO}_{3}^{-}$ concentrations in the water column were $<1 \mu \mathrm{M}$.

\section{DISCUSSION}

In the present study we found a significant difference between denitrification rates measured as nitrogen gas production in laboratory-incubated sediment and rates estimated from the nitrogen mass balance of the lake. The following hypotheses explaining this difference were evaluated: (1) The denitrification assay failed to measure factual nitrogen gas production. (2) The nitrogen mass balance 
obtained incorrect estimates of denitrification. (3) The sampled sediment was not representative of the lake. (4) The laboratory incubation system failed to simulate factors that control denitrification in the field.

Hypothesis 1: In a parallel experiment with sediment from this lake we have shown that the isotope pairing technique and the $\mathrm{N}_{2}$ flux method provided identical and reliable estimates of the denitrification activity (Risgaard-Petersen et al. 1998).

The tests performed in the present study also confirmed that potential artifacts associated with the denitrification assay can be excluded. If non-homogenous mixing of ${ }^{15} \mathrm{NO}_{3}{ }^{-}$and ${ }^{14} \mathrm{NO}_{3}{ }^{-}$in the sediment was a significant problem for the denitrification assay, then the estimated in situ denitrification activity would increase when the ${ }^{15} \mathrm{NO}_{3}{ }^{-}$concentration was elevated, because more of the activity would be detected as measurable ${ }^{29} \mathrm{~N}_{2}$ production (Nielsen 1992). Our data showed, however, that the estimate of the in situ denitrification activity was independent of the amount of added ${ }^{15} \mathrm{NO}_{3}{ }^{-}$(Table 1 ).

The indication that denitrification showed first order dependency of $\mathrm{NO}_{3}{ }^{-}$(Table 1) showed that the process was $\mathrm{NO}_{3}^{-}$limited. This confirmed that tracer additions did not interfere with the estimate of the in situ denitrification activity.

Constant production of ${ }^{29} \mathrm{~N}_{2}$ and ${ }^{30} \mathrm{~N}_{2}$, as indicated by linear ${ }^{29} \mathrm{~N}_{2}$ and ${ }^{30} \mathrm{~N}_{2}$ evolution with time (Figs. 2 \& 3), showed that the incubation time was sufficiently short to avoid significant depletion of the tracer and sufficiently long compared to the initial non-steady-state period when the ${ }^{15} \mathrm{NO}_{3}{ }^{-}$gradient is established in the sediment.

All tests performed in this study and the in study of Risgaard-Petersen et al. (1998) therefore indicate that the isotope pairing technique correctly measured actual denitrification in the laboratory-incubated sediment from Lake Søbygaard.

Hypothesis 2: The central parameters used in the mass balance model, e.g. water balance, nitrogen load, nitrogen export, and nitrogen burial, are all well described for this lake (Jensen et al. 1992), which justifies the denitrification estimate determined by this method. Since nitrogen burial in the lake is insignificant (Jensen et al. 1992), the indication by the mass balance approach of a $46 \%$ removal of the nitrogen input to the lake via denitrification is furthermore consistent with general trends for lakes and estuaries. Nixon et al. (1996) developed an empirical model to predict the percentage of total nitrogen input that is exported from lakes and estuaries from the hydraulic residence time $Q$ (unit for $Q$ is month):

$\%$ total nitrogen exported $=-27.0 \times \log (Q)+64.8$

The average hydraulic residence time for the lake in 1992 to 1993 was 0.83 mo (J. P. Jensen pers. comm.),

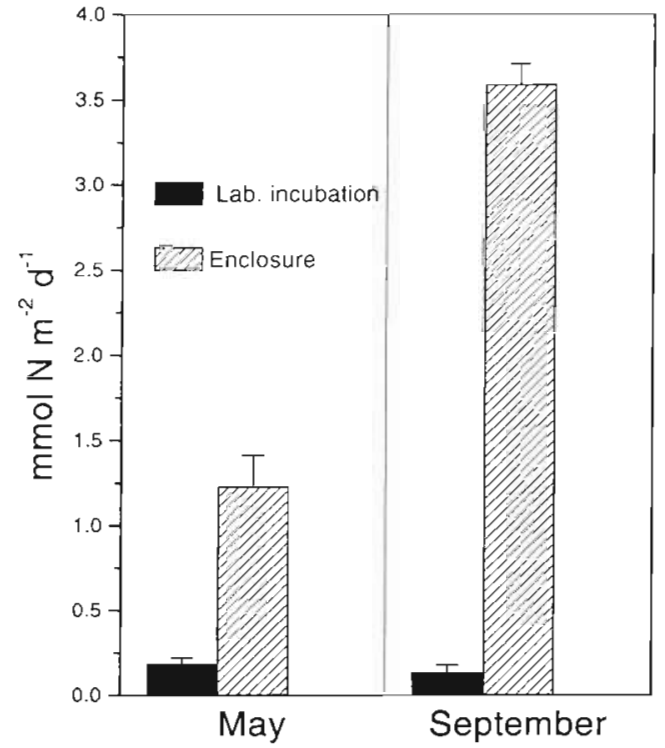

Fig. 6. Denitrification measured in the enclosure in the field and in the laboratory with the core-tube incubation technique. Error bars represent standard error of the mean $(n=6$ for the core-tube incubations; for the enclosures standard error is calculated from the regression data)

and according to Eq. (3) $33 \%$ of the nitrogen input to the lake would be removed ( $\%$ total nitrogen exported $=66.9)$. We therefore believe that the mass balance approach obtained reliable estimates of the denitrification activity in the lake.

Hypothesis 3: Results from our investigation of the spatial heterogeneity of denitrification activity in the lake sediment were not consistent with the hypothesis that non-representative sediment sampling was responsible for the divergence between laboratory measurements and the mass balance estimate. Similar denitrification rates were measured at the 3 sites in the lake, suggesting that the lake had a homogenous sediment environment.

Hypothesis 4: The observation that the denitrification activity measured in the field in the enclosures was 6 to 26 times higher than the activity measured in the laboratory-incubated cores, using the same methodolngy (Fig. 6), supports the hypothesis that the laboratory incubation system failed to simulate factors that control the in situ activity. We attribute these factors to mechanisms other than molecular diffusion controlling benthic solute exchange. Previous data of Sondergaard (1990) indicate that benthic solute exchange in the lake is controlled by such mechanisms. Sondergaard found both enhanced gross phosphorus release from the lake sediment compared to what could be estimated from porewater profiles, and rapid changes in the phosphate porewater profiles after storms. 
A mechanism responsible for benthic solute exchange in the lake might be porewater transport, induced by surface waves or the current. Movements of waves at the surface of the overlying water induce pressure changes which are transmitted into the sediment (Sleath 1984), and these repeated pressure changes generate flows of porewater in permeable sediments (Rutgers van der loeff 1981, Shum 1992). Interaction between water currents and the sediment topography may also generate pressure gradients and concurrent porewater flow (Huettel et al. 1996). This porewater flow acts in addition to molecular diffusion and can therefore enhance sediment-water exchange of solutes (Malan \& McLachlan 1991, Forster et al. 1996, Zeibis et al. 1996). Presence of wave- or currentinduced porewater flow is likely to enhance benthic denitrification, because the process is dependent on the rate of $\mathrm{NO}_{3}{ }^{-}$transport towards the anoxic denitrification zone (Seitzinger 1988, Christensen et al. 1989). If wave-induced porewater flow was significant in the sediment of the lake, highest denitrification activity would be expected in sediments incubated in the enclosures, since such porewater flow might act in the flexible field enclosures used in the present study, but evidently not in sediments isolated in rigid core tubes. The largest discrepancy between estimates obtained in the laboratory and in the field would furthermore be expected in periods with relatively high wind velocity, because surface waves are developed due to the friction between water and wind in the initial stage, and consequently larger pressure changes are transmitted into the sediment at high wind velocities than at low wind velocities. Both of these trends were observed in the present study (Fig. 6).

In the present study we have shown that the nitrogen gas production approach may obtain lower estimates of the denitrification activity than the mass balance approach. Our results are in accordance with previous studies showing that laboratory measurements may underestimate in situ denitrification activity in shallow lakes (Andersen 1977, van Luijn et al. 1996). Our data strongly indicate that this underestimation can be due to under-representation of in situ transport processes in the rigid core tubes used for labuiatury incubations, and we attribute these transport processes to wave-induced porewater transport. However, although this hypothesis appears attractive, we want to emphasize that the exact regulation of benthic denitrification in the lake is far from elucidated in this study. Indeed, more detailed studies on the effect of physical processes (waves, current, etc.) on the denitrification process are needed.

Acknowledgements. S. P. Andersen (AAU), E. Frandsen and K. Gerlich (NERI) are thanked for skilful technical assistance in the field and in the laboratory. J. P. Jensen (NERI) is thanked for 1992 to 1993 mass balance data. Three anonymous reviewers are acknowledged for their useful comments. The study was supported by the Center for Fresh Water Environmental Research under the Danish Strategic Environmental Research Program. This work is a contribution to the European Union ELOISE Program (ELOISE No. 076) in the framework of the NICE project carried out under contract MAS3-CT96-0048.

\section{LITERATURE CITED}

Andersen JM (1977) Rates of denitrification of undisturbed sediment from six lakes as a function of nitrate concentration, oxygen and temperature. Arch Hydrobiol 80(2): 147-159

Broecker WS, Peng TH (1974) Gas exchange between air and sea. Tellus $26: 21-35$

Christensen PB, Nielsen LP, Revsbech NP, Sørensen J (1989) Microzonation of denitrification activity in stream sediments as studied with a combined oxygen and nitrous oxide microsensor. Appl Environ Microbiol 55:1234-1241

Devol AH (1991) Direct measurements of nitrogen gas fluxes from continental shelf sediments. Nature 349:319-321

Forster S, Huettel M, Ziebis W (1996) Impact of boundary layer flow velocity on oxygen utilisation in coastal sediments. Mar Ecol Prog Ser 143:173-185

Grasshoff K, Erhardt M, Kremling K (1983) Methods of seawater analysis Verlag Chemie, Weinheim

Hansen AM, Christensen JV, Sortkjæer O (1991) Effect of high $\mathrm{pH}$ on zooplankton and nutrients in fishfree enclosures. Arch Hydrobiol 123:143-164

Huettel M. Zeibis W, Forster S (1996) Flow-induced uptake of particulate matter in permeable sediments. Limnol Oceanogr 41:309-322

Jensen JP, Jeppesen E, Kristensen P, Christensen PB, Søndergaard M (1992) Nitrogen loss and denitrification as studied in relation to reductions in nitrogen loading in a shallow hypertrophic lake (Lake Søbygård, Denmark). Int Rev Ges Hydrobiol 77:29-42

Jeppesen $E$, Søndergaard M, Mortensen E, Kristensen P, Rieman B, Jensen HJ, Müller JP, Jensen JP, Christoffersen K, Bosselman S (1990) Fish manipulation as a lake restoration tool in shallow, eutrophic temperate lakes 1: cross-analysis of three Danish case-studies. Hydrobiologia 200/201 205-218

Jeppesen E, Erlandsen M, Sondergaard M (1997) Can simple empirical equations describe the seasonal dynamics of bacterioplankton in lakes: an eight-year study in shallow hypertrophic and biologically highly dynamic Lake Søbygaard, Denmark. Microb Ecol 34:11-26

Jeppesen E, Jensen JP, Søndergaard M, Lauridsen T, Møller $\mathrm{PH}$, Sandby K (1998) Changes in nitrogen retention in shallow cutrophic lakes following a derline in density of cyprinids. Arch Hydrobiol 142:129-151

Kana TM, Darkangelo C, Hunt MD, Oldham JB, Bennet GE, Cornwell JC (1994) Membrane inlet mass spectrometer for rapid high-precision determination of $\mathrm{N}_{2}, \mathrm{O}_{2}$, and Ar in environmental samples. Anal Chem 66:4166-4170

Kana TM, Matthew BS, Cornwell JC, Groszkowski KM (1998) Denitrification in estuarine sediment determined by membrane inlet mass spectrometry. Limnol Oceanogr 43: $334-339$

Kanwisher J (1963) On the exchange of gases between the atmosphere and the sea. J Geophys Res 70:195-207

Malan DE, McLachlan A (1991) In situ benthic oxygen fluxes 
in a nearshore coastal marine system: a new approach to quantify the effect of wave action. Mar Ecol Prog Ser 73 $69-81$

Mengis M, Bernascino S, Gächer R, Wehrli B (1997) Nitrogenelimination in two deep eutrophic lakes. Limnol Oceanogr 42:1530-1543

Messer JJ, Brezonik PL (1978) Denitrification in the sediments of Lake Okeechobee. Verh Int Verein Limnol 20 $2207-2216$

Nielsen K, Nielsen LP, Rasmussen P (1995) Estuarine nitrogen retention independently estimated by the denitrification rate and mass balance methods: a study of Norsminde Fjord, Denmark. Mar Ecol Prog Ser 119:275-283

Nielsen LP (1992) Denitrification in sediments determined from nitrogen isotope pairing. FEMS Microbiol Ecol 86 $357-362$

Nishio T, Koike I, Hattori A (1983) Estimates of denitrification and nitrification in coastal and estuarine sediments. Appl Environ Microbiol 45:444-450

Nixon SW, Ammerman JW, Atkinson LP, Berounsky WM, Billen G, Boicourt WC, Boynton WR, Church TM, Ditoro DM, Elmgren R (1996) The fate of nitrogen and phosphorus at the land-sea margin of the North Atlantic Ocean. Biogeochemistry 35:141-180

Risgaard-Petersen N, Rysgaard S (1995) Nitrate reduction in sediments and waterlogged soils measured by ${ }^{15} \mathrm{~N}$ techniques. In: Alef $K$, Nannipieri $P$ (eds) Methods in applied soil microbiology. Academic Press Inc, London, p 287-296

Risgaard-Petersen N, Nielsen LP, Blackburn TH (1998) Simultaneous measurement of benthic denitrification with the isotope pairing technique and the $\mathrm{N}_{2}$ flux method in a continuous flow-through system. Water Res 32:3173-3176

Rutgers van der loeff MM (1981) Wave effects on sediment water exchange in a submerged sand bed. Neth J Sea Res 15:100-112

Rysgaard S, Christensen PB, Nielsen LP (1995) Seasonal variation in nitrification and denitrification in estuarine sedi-

Editorial responsibility: Gary King,

Walpole, Maine, USA ment colonized by benthic microalgae and bioturbating infauna. Mar Ecol Prog Ser 126:111-121

Seitzinger SP (1988) Denitrification in freshwater and coastal marine ecosystems: ecological and geochemical significance. Limnol Oceanogr 33:702-724

Seitzinger S, Nixon S, Pilson MEQ, Burke S (1980) Denitrification and $\mathrm{N}_{2} \mathrm{O}$ production in near-shore marine sediments. Geochim Cosmochim Acta 44:1853-1860

Seitzinger SP, Nielsen LP, Caffrey J, Christensen PB (1993) Denitrification measurements in aquatic sediments: a comparison of three methods. Biogeochem 23:147-167

Shum KT (1992) Wave-induced advective transport below a rippled water-sediment interface. J Geophys Res C Oceans 97:789-808

Sleath JFA (1984) Seabed mechanisms. Wiley and Sons, New York

Søndergaard M (1990) Pore water dynamics in the sediment of a shallow and hypertrophic lake. Hydrobiologia 192: $247-258$

Sorensen J (1978) Denitrification rates in a marine sediment as measured by the acetylene inhibition technique. Appl Environ Microbiol 36:139-143

Trimmer M, Nedwell DB. Sivyer DB, Malcolm SJ (1998) Nitrogen fluxes through the lower estuary of the river Great Ouse, England: the role of the bottom sediments. Mar Ecol Prog Ser 163:109-124

van Luijn F, Boers PCM, Lijklema L (1996) Comparison of denitrification rates in lake sediments obtained by the $\mathrm{N}_{2}$ flux method, the ${ }^{15} \mathrm{~N}$ isotope pairing technique and the mass balance approach. Water Res 30:863-900

Windolf J, Jeppesen E, Jensen JP, Kristensen P (1996) Modeling of seasonal variation in nitrogen retention and in-lake concentration: a four-year mass balance study in 16 shallow Danish lakes. Biogeochem 33:25-44

Zeibis W, Huettel M, Forster S (1996) Impact of biogenic sediment topography on oxygen fluxes in permeable seabeds Mar Ecol Prog Ser 140:227-237

Submitted: May 10, 1998; Accepted: October 10, 1998 Proofs received from author(s): June 7, 1999 